\title{
St. Sechnall's Hymn to St. Patrick
}

Author(s): Fr. Atkinson, St. Sechnall and Fr. Power

Source: The Celtic Review, Vol. 2, No. 7 (Jan., 1906), pp. 242-245

Stable URL: http://www.jstor.org/stable/30070154

Accessed: 27-06-2016 10:45 UTC

Your use of the JSTOR archive indicates your acceptance of the Terms \& Conditions of Use, available at

http://about.jstor.org/terms

JSTOR is a not-for-profit service that helps scholars, researchers, and students discover, use, and build upon a wide range of content in a trusted digital archive. We use information technology and tools to increase productivity and facilitate new forms of scholarship. For more information about JSTOR, please contact support@jstor.org. 
English Strath-rory, and the only other instance outside Sutherland known to me is Allt Uairidh, behind Abriachan, Inverness. It is probably a Pictish survival. Another term extremely common is rabhann, pronounced in some parts rafan, a species of grass growing in lochs of which sheep and cattle are fond. From it we have Bada-rabhainn, 'clump of ravan,' and such. It is probably to be connected with Welsh rafu, 'to spread '; rafon, 'berries growing in clusters.' Lòn in Sutherland means 'a slow burn,' as in Skye. Saidh, ' bitch,' occurs several times, as in Coire na Saidhe Duibhe, 'corry of the black bitch.' Preas regularly means ' copse,' not 'bush.' Diminutives in -ie are very common, e.g. alltaidh, 'a burnlet'; also dailidh, ' a little dale.'

\section{ST. SECHNALL'S HYMN TO ST. PATRICK}

Circ. A.D. 452 ; Translated from the original Celtic Latin by Fr. Atkinson, S.J., Wimbledon College

\section{With Introductory Note by Fr. Power, S.J., Edinburgh}

[Among Celtic scholars there is as much unanimity as to the very early date of the Hymn of St. Sechnall, as there is about the genuineness of the two documents written by the hand of St. Patrick - the Confession and the Epistle to Coroticus.

St. Sechnall's Hymn in honour of 'The Master of the Scots' cannot be dated later than A.D. 452, that is, about twenty years after the arrival of St. Patrick in Ireland. It is thus by far the earliest document, metrical or otherwise, written in Celtic Latin. Tradition ascribes it to Sechnall (Secundinus), the contemporary and kinsman of the Apostle of the Scoti.

The internal evidence (see especially Stanza I.) points unmistakably to the fact that when the poem was written St. Patrick was still alive and in the zenith of his fame.

Haddan and Stubbs, Bishop Dowden, and many others have remarked on the absence of any reference in the panegyric to the miracles of the man celebrated in Irish legends as the greatest Thaumaturgus since the days of the Twelve Apostles. The traditional explanation of the Irish legend is, that Patrick not only fell foul of his panegyrist, but ruthlessly revised many passages which he considered too complimentary to the 'rusticissimus peccator.' However that may be, the whole composition tends to show that all Scotia (Ireland) became Christian in an incredibly short time.

The evolution of the Continental Latin, first introduced with its script into Scotia by St. Patrick, is another interesting fact attested by the pseudo-classical alphabetic poem of St. Sechnall. No one, as far as I know, has yet noticed the extraordinary resemblance of St. Patrick's Latinity to that of St. Gregory of Tours. The latter wrote in what is now admitted to have been the vulgar tongue of Christian Europe in the fifth century. St. Sechnall, who must have been taught by some Italian of the CelestinoPalladio-Patrician mission, shows a marked advance on the portentous syntax of the uncouth Gaulish Latin of St. Patrick. The improvement was steadily maintained till 


\section{ST. SECHNALL'S HYMN TO ST. PATRICK}

it reached a very fair degree of perfection in the Latin works of St. Columbanus of Bangor, Yona, Luxeuil, and Bobbio.

The accompanying hymn was printed for the first time by Muratori. Its popularity in modern days has been quite eclipsed by the Eucharistic $\mathrm{H}_{y^{\prime} \mathrm{mn}}$ of St. Sechnall, found in the Antiphonary of Bangor, and beginningSancti venite, Christi Corpus sumite.

A good translation of the latter from the pen of Dr. Neale may be read in Hymns Ancient and Modern.

The best MS. of the 'Praise of St. Patrick' is to be found in the Book of Armagh. There is another venerable copy with a few variants, formerly preserved at St. Isidore's, Rome, but now transferred to the Franciscan monastery, Merchant's Quay, Dublin. This MS. in Stanza III. gives the reading Petrus, instead of Petrum, and is followed-I do not know why---by Haddan and Stubbs, and Cardinal Moran.

A rhymed translation of the following poem has been printed by Miss Cusack on pp. 597 sqq. of her immense volume, Trias Thaumaturga. Father Atkinson's version will, I think, be preferred. The worst that I can say of it is that, as a piece of poetry, it is superior to the original. The task of the translator was a difficult one. St. Sechnall's composition, however historically interesting, is little better than prose cut into lengths. Father Atkinson's duty was to eschew ornament, like his original, and yet to write poetry. His fidelity to St. Sechnall and his self-restraint in the use of poetic diction can only be appreciated by those who will compare his rendering with the Latin Hymn as given in Canon Warren's noble edition of the Antiphonarium Benchorense.

Readers acquainted with the muscular conciseness and elliptical Latin of St. Sechnall's Hymn to St. Patrick, beginning-

$$
\text { Audite omnes amantes, }
$$

may at first blush be surprised that the new translator, who is not new to poetry, should have chosen the far-extended line of the hexameter. Like other translators, he is under the law of faithfulness to the meaning of the first Irish poet, but no one would require of him to render a congested verse of somewhat 'barbarous' Celtic Latin by an equally short verse of English that would puzzle the modern reader and jar on the musical ear.]

Listen ye lovers of God as I tell you of Patrick the Bishop, Man whom the Master hath blest, hero of saintly deserts;

How for the good that he does upon earth, he is likened to angels, How for his life without flaw, peer of Apostles he stands.

Every tittle he guards of the mandates of Christ the All-Blesséd; Bright in the sight of the world glitters the light of his works;

Wondrous and holy indeed the example he sets and men follow, Praising the Lord for it all, praising the Father above.

Steadfast is he in the fear of his Maker; his faith is unshaken ; Firm as on Peter the Church rises up-builded on him ;

God hath allotted to him the place of Apostle within it, 'Gainst it the portals of hell never are strong to prevail.

Him hath the Master elected a teacher of barbarous races, Cunning with seine of the truth, fishing for men with his net,

So that from waves of the world he may win unto grace the believing, Making them follow their Lord up to His throne in the skies. 
Christ's are the talents he sells, the excellent coin of good tidings, Claiming them back from our clans, fruitful with usury's gain;

Certain for meed of his toil, for price of his prodigal labour, Some day with Christ to possess joy in His heavenly realm.

Faithful in service to God is he-God's most glorious envoy, Model and type to the good what an Apostle should be,

Preacher with word and with action to such as God calls for His people, So that if word be too weak, action may urge them to good.

Christ hath his glory in keeping, yet here upon earth is he honoured, Worshipped by all who behold, e'en as an angel of God;

Yea, for as Paul to the Gentiles, so God hath sent him His Apostle, Guiding the steps of men home, unto the Kingdom of God.

Humble in spirit and body, the fear of his Maker hath filled him, Though for his goodness the Lord loveth to rest on his soul;

Deep in his flesh that is sinless he carries the mark of the Master, Patiently bearing nor e'er glorying save in the Cross.

Dauntless and restless he feeds the believing with heavenly banquets, Lest they that journey with Christ, faint as they walk on the road, Furnishing forth unto all for their bread the words of the GospelLo! as the manna of old-multiplied still in his hands.

Chaste for the love of his Lord, he warily keepeth his body Wrought and adorned as a shrine, meet for the Spirit of God :

Yea, and the Spirit for ever abides amid works that are cleanly, Yea, 'tis a victim he gives living and pleasing to God.

Light of the world is he, kindled ablaze, as was told in the Gospel, Lighted and set on the stand, shining far out to mankind :

Stronghold is he of the King, a city placed high on the hill-topPlentiful riches are there, stored for the Master of all.

Surely shall Patrick be called in the heavenly kingdom the greatest, Who what his holy words teach, bodies in goodness of deed;

Pattern and model of all, he guides the van of the faithful, Keeping in pureness of heart trust ever clinging to God.

Boldly he blazons the name of the Lord to the infidel races, Giving them grace without end, out of the laver of life.

Day after day for their sins unto God he makes his petition, Slaying for health of their souls victims worthy of God.

Worldly acclaim doth he flout, that God's law may yet be established, While at God's Table he stands, all is as dross in his eyes;

Thunder of this world may crash; undaunted he faces its crashing, Glad in the tempest of wrong, since that he suffers for Christ. 


\section{ST. SECHNALL'S HYMN TO ST. PATRICK}

Shepherd so faithful and true of the flock that the Gospel has won him, Chosen by God's own self ward of the people of God,

Chosen to pasture His people with teaching appointed from heaven, Risking his life for the flock, after the pattern of Christ.

Him hath the Saviour raised to be Bishop because of his merits, Counsellor unto the priests fighting the battle of God,

Giving them raiment to wear and food from a heavenly storehouse, Holy celestial words, quitting his task to the full.

Lo! to the faithful he bears the call of the King to His nuptials, Wearing the nuptial robe, clad with the garment of grace.

Heavenly wine doth he draw without stint in celestial vessels, Bidding God's people approach unto the heavenly cup.

Hid in the sacred Books, a sacred treasure he found him, Seeing the Godhead clear under the Saviour's Flesh,

Holy and all complete are his merits that purchase the treasure.

'Warrior of God,' is he called, looking on God with his soul.

Faithful witness is he of the Lord in Catholic precepts, Precepts carefully stored, salt with the message divine;

So that man's flesh may never corrupt into food for the earth-worms, Kept by the heavenly juice fresh to be offered to God.

Labourer noble and loyal is he in the field of the Gospel, Sowing in sight of the world seeds of good tidings of Christ;

Sowing with lips that God guards seed in the ears of the wary, Making their hearts and their minds tilth of the Spirit of God.

Christ for Himself hath made ckoice; His deputy here hath He placed him, Out of two tyrants' holds setting their prisoners free-

Ransoming slaves from the chains of men who held them in bondage, Freeing from Satan's rule numberless souls that were his.

Hymns and psalms doth he sing to the Lord with St. John's Revelations; Chanting to hasten his work, building the people of God.

Into their keeping he gives the law in the Name of the Triune, Teaching the Persons are Three, simple the Substance of God.

Girt with the girdle of God, by day and by night never ceasing Unto his Lord and his God, riseth his prayer without rest;

Mighty the toil is, and sure the guerdon that waits for his labourLordship along with the Twelve over the people of God.

Listen ye lovers of God as I tell you of Patrick the Bishop, Man whom the Master hath blest, hero of saintly deserts;

How for the good that he does upon earth, he is likened to angels How for his life without flaw, peer of Apostles he stands. 